\title{
Prospective Primary School Teachers' Attitudes Towards Teaching Mathematics
}

\author{
Mesut Tabuk ${ }^{1}$ \\ ${ }^{1}$ Faculty of Education, Canakkale Onsekiz Mart University, Canakkale, Turkey \\ Correspondence: Mesut Tabuk, Faculty of Education, Canakkale Onsekiz Mart University, Canakkale, Turkey.
}

Received: April 10, 2018

Accepted: April 30, 2018 Online Published: May 15, 2018

doi:10.5539/jel.v7n4p225

URL: https://doi.org/10.5539/jel.v7n4p225

\begin{abstract}
The aim of the study is to determine prospective primary school teachers' attitudes towards teaching mathematics. The study is designed according to model of survey in the descriptive type. A total of 236 prospective primary school teachers were examined in order to investigate the effect of gender and program differences on their attitudes towards teaching mathematics. In the study, the questionnaire "Teaching Mathematics" was used to collect the data from prospective teachers. The results revealed that the prospective teachers have positive attitude towards teaching mathematics. It was found also that gender and grade level are not significant factor on attitude scores. Finally, various suggestions were presented for future studies in accordance with the findings obtained.
\end{abstract}

Keywords: attitude towards teaching mathematics, prospective teachers, primary school, gender, grade

\section{Introduction}

Recently policy makers, playing a very significant role in the educational systems; governments and education organizations, have begun to show a growing interest in teacher qualifications in order to in improve school quality and student outcomes (OECD, 2016). The most crucial indicator of teacher quality is the pedagogical knowledge of teachers (Guerriero, 2014). However, it is necessary not only to consider the teachers' pedagogical content knowledge but it has also been accepted that the teachers' attitudes are important determinant for the teacher qualification (McLeod, 1992).

In the consideration of teacher quality, a large number of investigations focus on two main title; cognitive factors (Kanes \& Nisbet, 1994) and affective factors (Ball, 1988). Maker (1982) also emphasized that there is important relationship between affective and cognitive domain. It is impossible to separate each other. But affective factors are generally considered ambiguous and difficult to understand. McLeod (1992) identifies three basic concepts to describe the affective factors in mathematics education: attitudes, beliefs and emotions.

\subsection{Teachers' Attitudes}

Among the researches on affect, the attitude has perhaps the longest history and the highest popularity in mathematics education (Zan et al., 2006). Many researchers have revealed that the students' attitude towards mathematics is one of the most important factors related to their achievement in mathematics (Ma \& Kishor, 1997).

Teachers', especially prospective teachers' attitudes — not only towards mathematics, but also towards teaching of mathematics - are important because there is a significant relation between teachers' attitudes towards teaching mathematics and their practice in teaching mathematics. As a result, they have a powerful influence on the students' attitudes towards mathematics (Ernest, 2004). It is reported that the mental, physical and social development of children is quite rapid during the early childhood period. As a result, the development during the primary education period is particularly important for the future of the children. Because of this reason, primary school teachers have powerful impact on the mathematics achievement of children (Frakes \& Kline, 2000).

Attitude towards mathematics is important, because they are it is one of the most important factors, affect the math achievement. Measuring attitude is not the solution of the problem. It should be investigated the factors influencing attitude. If the main idea is to change attitude towards mathematics in positive direction, it is necessary to know the manipulative factors on attitude. 
These manipulative factors is identified under three main groups; factors related to personal characteristics, factors related to the school environment and the home environmental factors and society. In the literature, the multitude of personal characteristics have been emphasized (Nicolaidou \& Philippou, 2003).

\subsection{Attitude Related Factors; Gender, Age and Year of Study}

Gender is accepted a significant predictor of attitude towards mathematics. Although mathematics is perceived as a male dominated field (Ernest, 2004), there is no a clear consensus about gender differences throughout the literature in academic studies and it is an important phenomenon. Some research findings have shown that girls are better than boys in mathematics, while others revealed opposite. On the other hand, some other results also show no difference between boys and girls.

According to findings of some researches, frequent and repeated failures in mathematics achievement resulted in negative attitude towards mathematics. Although when they start the school life, students have a positive attitude, in course of time, their attitudes become more and more negative with the school grade (Nicolaidou \& Philippou, 2003).

Considering the research literature about the attitude towards mathematics, mentioned above, the main purpose of the research is to determine prospective primary school teachers' attitudes towards teaching mathematics. For this main purpose, in the study the following research questions are determined.

1) Is there a significant gender difference in the prospective teachers' attitudes to teaching mathematics?

2) Is there a significant grade level difference in the prospective teachers' attitudes to teaching mathematics?

\section{Method}

\subsection{Design}

The present study is a quantitative study conducted using the survey method. Survey design enables the quantitative or numerical description of tendencies, attitudes or views in a population by studying a sample selected within the population (Creswell, 2014).

\subsection{Participants}

This research has been executed at a university in the western part of Turkey in 2015-16 academic sessions. A total of 236 prospective teachers, from primary school education department, participated in the research. The prospective teachers' age range is between 18 and 28 . The sample was predominantly female: 194 out of 236 (92\%). The majority of the students are juniors (57\%). Details about the participants are given in Table 1 .

Table 1. Distribution of prospective teachers

\begin{tabular}{llll}
\hline Grade & Gender & $\mathbf{N}$ & $\mathbf{\%}$ \\
Freshmen & Female & 83 & 35 \\
& Male & 18 & 8 \\
& Total & 101 & 43 \\
Juniors & Female & 111 & 47 \\
& Male & 24 & 10 \\
& Total & 135 & 57 \\
\hline
\end{tabular}

Before the application, the voluntary participants are informed about the purpose of the study. On average, each participant took almost 15 minutes to complete the questionnaire. The questionnaire was applied by the researcher. The data were gathered in the last week the course.

\subsection{Instruments and Data Analysis}

Data was gathered using an attitude survey. The survey, the "Teaching Mathematics Questionnaire", has 20 items required Likert scale responses. The survey's 11 items is related to determination attitude towards teaching of mathematics. The other 9 items is about attitude towards mathematics. The instrument was developed by Relich \& Way (1992) in English. The reliability test of the original attitude questionnaire is determined by calculating Cronbach alpha coefficient. As a result, it is found that the two sub-scales of the survey are highly reliable. The adaptation of the scale to the Turkish language was carried out by Tabuk \& Tabuk (2018). The study revealed the scales of the structures fully adhere to the English. The internal consistency of the two subscales that determine attitude towards mathematics teaching and attitude towards mathematics in the Turkish form of the measurement tool were .82 and .85 , respectively. 
In analysis of gathered data from 236 participants, SPSS 21 is used. For comparative analysis, t-test is used in order to examine the changes depending on grade and gender variables.

\section{Results}

\subsection{Results Related to First Research Questions}

In the answer of this question, independent two sample t-test was conducted. The results of the analysis according to the grade level about the prospective primary school teachers' attitudes towards teaching mathematics are given in Table 2 .

Table 2. Test results for grade differences

\begin{tabular}{llllllll}
\hline Variable & Group & $\mathrm{N}$ & Mean & $\mathrm{sd}$ & $\mathrm{df}$ & $\mathrm{t}$ & $\mathrm{p}$ \\
\hline \multirow{2}{*}{ Grade } & Freshmen & 101 & 5.00 & 1.06 & \multirow{2}{*}{234} & \multirow{2}{*}{.340} & \multirow{2}{*}{.734} \\
& Juniors & 135 & 4.95 & 1.10 & & & \\
\hline
\end{tabular}

Note. ${ }^{*} \mathrm{p}<.05$

The findings, presented on the Table 2 above, showed that there is no significant difference between the average scores of the prospective primary school teachers in terms of their grade level $(t(234)=-2.027, p>.05)$. As a result, it can be said that freshmen and juniors prospective preschool teachers have same attitude level towards teaching mathematics.

\subsection{Results Related to Second Research Questions}

When the mean scores of prospective teachers' attitudes towards teaching mathematics have been analyzed in terms of the gender, independent two sample t-test has been applied and the result the test is presented in Table 3.

Table 3. Test results for gender differences

\begin{tabular}{llllllll}
\hline Variable & Group & $\mathrm{N}$ & Mean & $\mathrm{sd}$ & $\mathrm{df}$ & $\mathrm{t}$ & $\mathrm{p}$ \\
\hline \multirow{2}{*}{ Gender } & Female & 194 & 4.97 & 1.11 & \multirow{2}{*}{234} & \multirow{2}{*}{.156} & \multirow{2}{*}{.876} \\
& Male & 42 & 4.95 & .94 & & \\
\hline
\end{tabular}

Note. ${ }^{*} \mathrm{p}<.05$.

To determine whether the prospective teachers' attitudes towards teaching mathematics changes with gender, independent two samples t-test was applied $(\mathrm{t}(234)=.156, \mathrm{p}>.05)$. The mean score for male $($ Mean $=4.95)$ and female (Mean $=4.97$ ) indicated that male scored more favorable attitude towards teaching mathematics than male.

\section{Discussion}

In this study, the main purpose was to determine prospective primary school teachers' attitudes towards teaching mathematics. In general, the study has indicated that the prospective teachers' attitudes towards teaching mathematics is positive (Mean=4.97). This result is supported by the other researchers' findings (Tarım \& Bulut, 2006; White, Way, Perry, \& Southwell, 2005). When considering the reasons of the results, it was explained in the literature that the subjects of mathematic lessons at the primary school level are basics and easy for the teachers (Tarım \& Bulut, 2006).

The findings of the test also presented that there is no significant difference between the attitude scores of the freshmen and juniors of the prospective primary school teachers. These results are in parallel with some studies (Tarim \& Bulut, 2006; Way \& Relich, 1993). It is generally expected that prospective primary teachers' attitudes towards teaching mathematics change in positive direction as they progressed through the programs. Especially, the senior prospective teachers are involved in practicum experiences and have already completed the required courses about mathematics teaching methods (Way \& Relich, 1993)

It was found also that gender was not a significant factor on the total attitude score. According to the test results, the mean score for male and female indicated that female scored more favorable attitude towards teaching mathematics than male. This result is supported by another researcher's findings (Relich, 1996) which claim that there is gender difference between female and male teachers' attitudes to teaching mathematics. 
Finally, based on the findings and evaluations of the paper it is firstly recommended to conduct subsequent longitudinal studies including prospective teachers from different programs. It is also recommended to investigate how prospective teachers' attitudes are affected by different variable; departments, academic achievement and age. Comparative studies with large numbers of prospective teachers across locations are recommended as well.

\section{References}

Ball, D. L. (1988). Unlearning to teach mathematics. For the Learning of Mathematics, 8(1), 40-47.

Creswell, J. W. (2014). Research Design: Qualitative, Quantitative and Mixed Methods Approaches (4th ed.). London: Sage Publications Ltd.

Dowker, A., Bennett, K., \& Smith, L. (2012). Attitudes to Mathematics in primary school children. Child Development Research. https://doi.org/10.1155/2012/124939

Ernest, P. (2004). Images of mathematics, values and gender. In S. Johnston-Wilder \& B. Allen (Eds.), Mathematics education: exploring the culture of learning. London, New York: Routledge.

Frakes, C., \& Kline, K. (2000). Teaching young mathematicians: The challenges and rewards. Teaching Children Mathematics, 6(6), 376-381.

Guerriero, S. (2014). Pedagogical Knowledge and the Changing Nature of the Teaching Profession. Paris: OECD Publishing.

Kanes, C., \& Nisbet, S. (1994). An investigation into the knowledge bases of primary and secondary mathematics teachers: Report on a pilot study. Proceedings of 17th annual conference of the Mathematics Education Research Group of Australasia (pp. 363-372). Lismore.

Ma, X., \& Kishor, N. (1997). Assessing the relationship between attitude towards mathematics and achievement in mathematics: A meta-analysis. Journal for Research in Mathematics Education, 28(1), 26-47. https://doi.org/10.2307/749662

Maker, C. J. (1982). Teaching models in education of the gifted. Rockville, MD: Aspen Systems Corp.

McLeod, D. (1992). Research on affect in mathematics education: A reconceptualization. In D. Grows (Ed.), Handbook of research on mathematics teaching and learning (pp. 575-596). New York: McMillan. Retrieved from http://www.peterliljedahl.com/wp-content/uploads/Affect-McLeod.pdf

Nicolaidou, M., \& Philippou, G. (2003). Attitude towards mathematics, self-efficacy and achievement in problem-solving. Proceedings of the 3rd Conference of the European Society for Research in Mathematics Education, University of Pisa, Italy

OECD. (2016). PISA 2015 Assessment and Analytical Framework: Science, Reading, Mathematic and Financial Literacy. Paris: PISA, OECD Publishing. https://doi.org/10.1787/9789264255425-en

Relich, J. (1996). Gender, self-concept and teachers of mathematics: effects on attitudes to teaching and learning. Educational Studies in Mathematics, 30(2), 179-195. https://doi.org/10.1007/BF00302629

Relich, J., \& Way, J. (1992). Pre-service primary teachers' attitudes to teaching mathematics: A reappraisal of a recently developed instrument. Fifteenth Annual Conference of the Mathematics Association of Australasia: Conference Proceedings. Richmond, N. S. W.

Tabuk, M., \& Tabuk, M. (2018). Öğretmen adaylarının matematiğe ve matematik öğretimine ilişkin tutumları. Anadolu Üniversitesi Eğitim Fakültesi Dergisi (AUJEF), 2(1), 52-66.

Tarım, K., \& Bulut, S. (2006). Okulöncesi öğretmenlerinin matematik ve matematik öğretimine ilişkin algı ve tutumları. Çukurova Üniversitesi Ĕgitim Fakültesi Dergisi, 2(32), 152-164.

Way, J., \& Relich, 1. (1993). Development of positive attitudes to mathematics: the perspective of pre-service teachers. Proceedings of the Sixteenth Annual Conference of the Mathematics Education Research Group of Australasia. Brisbane.

White, A. L., Way, J., Perry, B., \& Southwell, B. (2005). Mathematical Attitudes, Beliefs and Achievement in Primary Preservice Mathematics Teacher Education. Mathematics Teacher Education and Development, 7, 33-52.

Zan, R., Brown, L., Evans, J., \& Hannula, M. S. (2006). Affect in mathematics education: An introduction. Educational Studies in Mathematics, 63(2), 113-121. https://oi.org/10.1007/s10649-006-9028-2 


\section{Copyrights}

Copyright for this article is retained by the author(s), with first publication rights granted to the journal.

This is an open-access article distributed under the terms and conditions of the Creative Commons Attribution license (http://creativecommons.org/licenses/by/4.0/). 